\title{
The Formation of Verbs of Emotion in Arabic
}

\author{
Abdallah Alshdaifat * \\ Department of Arabic, University of Jordan, Jordan
}

Received on: 9-4-2020

Accepted on: 30-6-2020

\begin{abstract}
This study aims to explore the characteristics of the formation of Arabic verbal forms within the semantic field of emotions. The paper adopts an analytical statistical method to provide a comprehensive analysis involving three aspects: word-formation of each verbal form; syntactic behaviour of each verbal form in terms of transitivity; and the existence of underived verbal forms in Jordanian Arabic. It examines the derivation of the ten verbal forms (Form I - Form X) from 100 roots within the semantic field of emotions by checking their existence in Arabic dictionaries. The analysed data shows that a Form I verb (the base form in Arabic) is derived 171 times by applying six canonical patterns to 100 roots, generalising that Form I verbs of emotions tend to follow the pattern $C_{1} a C_{2} i C_{3}$. On the other hand, each of Form II - Form X has a single canonical pattern; applying these patterns to a given root leads to an augmented verb. However, the analysed data shows that 350 Form II - Form X verbs have been derived. The study concludes that the highest derivable form is Form IV, while Form IX is not derived within this semantic field. The study also examines the syntactic behaviour of Form I - Form X verbs, and the analysed data shows a sharp shift from one form to another. Furthermore, in terms of the underived Arabic verbal forms (Form II - Form X) which are not listed in Arabic dictionaries, this study examines their existence in Jordanian Arabic. The findings could be the basis of further work on other semantic fields such as verbs of motion, verbs of social interaction, and verbs of mental process. The outcome of this study will be also useful for NLP applications such as Arabic e-dictionaries, wordnet and ontology applications.
\end{abstract}

Keywords: Verbs of Emotion, Arabic Morphology, Verbal Derivation, Jordanian Dialect.

\section{Theoretical framework}

\subsection{Arabic verbal morphology}

The Arabic morphology is characterised by nonconcatenative structures, in which the word formation is not based on linking/adding morphemes as is the case in concatenative morphological structures such as English. Word formation in Arabic involves nonconcatenative word-formation processes including template change, affixation and gemination to create new stems (Alshdaifat 2014). Derivationally, Arabic verb stems are classified into thirteen forms. They are labelled in modern

๑ 2021 JJMLL Publishers/Yarmouk University. All Rights Reserved,

${ }^{*}$ Doi: https://doi.org/10.47012/jjmll.13.1.7

* Corresponding author: a.shdaifat@ju.edu.jo 
linguistics using Roman numerals (Form I - Form XIII), ten of which (Form I - Form X) are commonly used in Modern Standard Arabic (MSA). These verb stems are governed by canonical patterns that include slots for consonants and vowels, conveying functional meanings as well as grammatical and syntactic information (cf. Watson 2002).

The morphological pattern Form I stem (CVCVC) comprises three positions of the root consonants and vocalic melody interdigitating between root consonants. The root in Arabic is a dependent morpheme comprising three consonants, which does not act as an independent word (stem). For instance, the verb stem farih 'to be happy' comprises three root consonants $f-r-h$ and two interdigitated vowels $-a-i-$, as shown in Figure 1.

\section{Three Root Consonants' Positions}

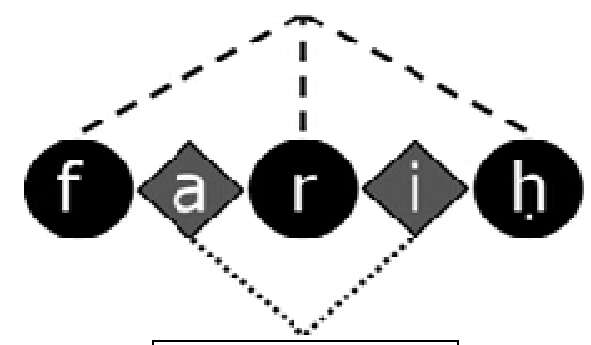

Figure 1: Form I pattern structure

\section{Two Vowels Positions}

Taking the perfect-imperfect mapping, the Form I verb stem has six morphological patterns in Arabic (see Table 1). These patterns have three slots for three root consonants and two intervening slots for vowels. A given root usually selects a specific pattern of those six patterns irregularly, to determine which pattern is in use; even an Arabic native speaker needs to verify the morphological pattern in classical Arabic dictionaries. More challengingly, some roots take more than one pattern, for example, three Form I verb stems with different patterns are derived from the root $\boldsymbol{h}-\boldsymbol{z}-\boldsymbol{n}$ : (1) $\boldsymbol{h}$ azan - yahzun 'to feel sad', (2) hazin - yahzan (also) 'to feel sad', and (3) hazun-yahzun 'to be or become rough'. These three verbs differ semantically, and they also differ syntactically where the first verb is transitive, while the second and third are intransitive.

Table 1: Morphological patterns of Form I verb stem.

\begin{tabular}{|c|c|c|c|c|c|}
\hline Pattern 1 & Pattern 2 & Pattern 3 & Pattern 4 & Pattern 5 & Pattern 6 \\
\hline Perfect Imperfect & Imperfect & Imperfect & Imperfect & Imperfect & Imperfect \\
\hline $\mathrm{C}_{1} \mathrm{aC}_{2} \mathrm{aC}_{3} \mathrm{yaC}_{1} \mathrm{C}_{2} \mathrm{uC}$ & $\mathrm{C}_{1} \mathrm{aC}_{2} \mathrm{aC}_{3} \mathrm{yaC}_{1} \mathrm{C}_{2} \mathrm{iC}_{3}$ & ${ }_{3} \mathrm{C}_{1} \mathrm{aC}_{2} \mathrm{aC}_{3} \mathrm{yaC}_{1} \mathrm{C}_{2} \mathrm{aC}$ & ${ }_{3} \mathrm{C}_{1} \mathrm{aC}_{2} \mathrm{iC}_{3} \mathrm{yaC}_{1} \mathrm{C}_{2} \mathrm{aC}_{3}$ & ${ }_{3} \mathrm{C}_{1} \mathrm{aC}_{2} \mathrm{iC}_{3} \mathrm{yaC}_{1} \mathrm{C}_{2} \mathrm{iC}_{3}$ & ${ }_{3} \mathrm{C}_{1} \mathrm{aC}_{2} \mathrm{uC}_{3} \mathrm{yaC}_{1} \mathrm{C}_{2} \mathrm{uC}$ \\
\hline $\begin{array}{l}\text { E.g. from the root: } \\
\boldsymbol{h}-\boldsymbol{s}-\boldsymbol{d}\end{array}$ & $\begin{array}{l}\text { E.g. from the root: } \\
c_{-t}-\boldsymbol{b}\end{array}$ & $\begin{array}{l}\text { E.g. from the root: } \\
f_{-j-c}\end{array}$ & $\begin{array}{l}\text { E.g. from the root: } \\
\boldsymbol{f}-\boldsymbol{r}-\boldsymbol{h}\end{array}$ & $\begin{array}{l}\text { E.g. from the root: } \\
y-{ }^{-}-s\end{array}$ & $\begin{array}{l}\text { E.g. from the root: } \\
\boldsymbol{m}-\boldsymbol{q}-\boldsymbol{t}\end{array}$ \\
\hline hasad yahsud & ${ }^{c} a t a b \quad y a^{c} t i b$ & $f a j a^{c} \quad y a f j a^{c}$ & farih yafrah & ya is $\quad y a y^{\curvearrowright} i s$ & yamqut \\
\hline 'to envy' & 'to blame' & 'to shock' & 'to be happy' & 'to lose hope' & 'to hate' \\
\hline
\end{tabular}

* $\mathrm{C} 1, \mathrm{C} 2$, and $\mathrm{C} 3$ represent the first, second, and third consonantal root letters respectively.

The first three patterns, which share the same pattern in the perfect tense $C_{1} a C_{2} a C_{3}$, typically involve a transitive meaning, and they usually express semantics that involve making, working, or moving (motions). The fourth and the fifth patterns, which share the same pattern in the perfect tense $C_{1} a C_{2} i C_{3}$, 


\section{The Formation of Verbs of Emotion in Arabic}

mainly express semantics that involve temporary qualities, and are usually associated with intransitive verbs. The sixth pattern $C_{1} a C_{2} u C_{3}$, which is always associated with intransitive verbs, mainly expresses the semantics of permanent qualities.

In Arabic, the Form I verb is the input for deriving nine derived verb stems (Form II - Form X); see Table 2. The derived verbs, which share a given root, are semantically related and convey a core lexical meaning. For instance, the Form I verb $\boldsymbol{h} a \boldsymbol{b} \boldsymbol{b}$ 'to love' derives six verb forms: Form II $\boldsymbol{h} \boldsymbol{a} \boldsymbol{b} \boldsymbol{b} \boldsymbol{a b}$ 'to cause someone to love something or someone', Form III $\boldsymbol{h} \bar{a} \boldsymbol{b} \boldsymbol{b}$ 'to act in a loving manner with someone', Form

IV 'ahabb 'to adore', Form V tahabbab 'to show love or affection to', Form VI tahābb 'to exchange/share love', and Form IX istahabb 'to favour'.

Table 2: Patterns of Form I verb stem.

\begin{tabular}{|c|c|c|}
\hline Form & Pattern & Example \\
\hline Form I & $C_{1} a C_{2} a C_{3}$ & hasad 'to envy' \\
\hline Form II & $C_{1} a C_{2} C_{2} a C_{3}$ & $\boldsymbol{x}$ ajjal 'to cause feeling shame' \\
\hline Form III & $C_{1} \bar{a} C_{2} a C_{3}$ & cätab 'to admonish' \\
\hline Form IV & ${ }^{a} a C_{1} C_{2} a C_{3}$ & `abhaj 'to make someone happy' \\
\hline Form V & $\operatorname{taC}_{1} a C_{2} C_{2} a C_{3}$ & ta) \\
\hline Form VI & $\operatorname{ta}_{1} \bar{a} C_{2} a C_{3}$ & takārah 'to hate' \\
\hline Form VII & $\sin _{1} a C_{2} a C_{3}$ & 'inzacaj 'to feel upset' \\
\hline Form VIII & ${ }_{i} C_{1} t_{a} C_{2} a C_{3}$ & 'ikta $a \boldsymbol{b}$ 'to be aggrieved' \\
\hline Form IX & ${ }^{\circ} C_{1} C_{2} C_{2} a C_{3} C_{3}$ & ihmarr 'to be red' \\
\hline Form X & ${ }^{2} i s t a C_{1} C_{2} a C_{3}$ & 'istay'as 'to lose hope (of)' \\
\hline
\end{tabular}

* $\mathrm{C} 1, \mathrm{C} 2$, and $\mathrm{C} 3$ represent the first, second, and third consonantal root letters respectively.

The derivational relations among the derived forms have been clearly reported. Watson (2006: 432) states that "Forms II, III, and IV are derived from Form I by extension of the stem; Forms V and VI are derived by prefixation of $t a$ - to Forms II and III, respectively. Forms VII, IX, and X involve various types of prefixation, and Form VIII is derived from Form I by infixation of /t/ after the leftmost root consonant. No consonantal root in Modern Standard Arabic has all ten verb forms, and a few verbs have one or more derived forms but lack the basic form”.

In what follows, this study provides a comprehensive analysis of ten derived verb forms (Form I Form X). This analysis involves three levels: (1) statistical analysis to determine the frequency of deriving each form of the derived verbs (Form II - Form X) from a Form I verb; (2) the syntactic behaviour of the derived forms; and (3) the existence of underived verb forms of emotion in Jordanian dialects that are not found in standard Arabic.

\subsection{Verbs of Emotion}

Cross-linguistically, verbs of emotion convey subjective qualities that someone feels. These qualities express internal feelings or interactive feelings towards the world around us. In the literature, they have been classified by Ekman (1972) into six basic emotions: joy, surprise, anger, fear, disgust, and sadness.

Plutchik (1980) proposed eight emotions: joy, trust, fear, surprise, sadness, disgust, anger and anticipation.

In this study, the situations in which verbs of emotion are used could involve positive emotional situations: happiness, admiration, love, and surprise, and negative emotional situations: sadness, hate, 
anger, fear, and regret. The study's classification of Arabic verbs of emotion corresponds to Levin (1993) and Vendler's (1968) verb classification of English verbs. Levin (1993) classified verbs of emotion such as fear, enjoy, scare, shame, and shock under "verbs of psychological state". By way of contrast, in Vendler's classification these verbs are part of a loose class titled "state verb class".

The verbs of emotion have been semantically analysed by Alshdaifat (2015) in terms of the object entity and the situation entity as follows: the former type is a subclass of verbs which refer to abstract entities, expressing non-physical, unseen and intangible meanings (which are not accessible to any of the five senses) that do not occupy physical space, such as to love, to hate and to fear. The latter type refers to verbs denoting state entities, describing a state which is permanent or will last for a significant time.

\subsection{Material and methodology}

The linguistic data in this study are grouped in three parts: (i) corpus of 100 triconsonantal roots which refer to emotions, (ii) 171 Form I verbs which are formed from the 100 roots; (iii) 350 Form II Form $\mathrm{X}$ verbs derived from these roots. Nine derived verb forms are expected to be derived from each root, giving potentially 900 derived verb stems. However, only 350 verbs are derived which do exist in Arabic dictionaries, an average of from a given Form I verb of emotions of 3.5 verbs.

Alshdaifat (2015) provided a semantic classification of verbs in which Form I verbs have been classified into 44 semantic classes. One of these is the class of verbs of emotion, which includes 48 verb roots. This class has been expanded in this study to include 100 roots that refer to emotions. The criteria by which verbs are included or excluded is using the gerund of a given verb with the verb šacartu 'I feel' as a running sentence, as in this frame: [Subject + Verb 'to feel' + Gerund of a verb of emotion], for example, the verb hazun 'to be sad' šacartu bilhuzn 'I felt sad'. Following Alshdaifat (2015) with some modifications, 44 verb roots have been selected.

In this study, looking up Arabic dictionaries, 171 Form I verbs of emotion have been derived from 100 triliteral roots. The derivation from the roots is varied, with the average of derivation from each root approximately three Form I verbs. These verbs were analyzed in terms of their morphological patterns and their transitivity/intransitivity. As illustrated in Table 3, Pattern $4 C_{1} a C_{2} i C_{3}-y a C_{1} C_{2} a C_{3}$ is the dominant morphological pattern among the verbs of emotion, with an average of $74 \%$, followed by pattern 2 and pattern 1 with 33\% and 32\% respectively. Most pattern 4 verbs are intransitive, and the verbs of emotion with this pattern are typically intransitive.

Table 3: Frequency of patterns' transitivity of verb Form I

\begin{tabular}{lllllll}
\hline & Pattern 1 & Pattern 2 & Pattern 3 & Pattern 4 & Pattern 5 & Pattern 6 \\
\hline Derivation & 31 of 100 & 33 of 100 & 13 of 100 & 74 of 100 & 14 of 100 & 5 of 100 \\
Transitive & 10 of 32 & 8 of 33 & 7 of 13 & 6 of 74 & 0 of 14 & 0 of 5 \\
Intransitive & 4 of 32 & 7 of 33 & 1 of 13 & 56 of 74 & 14 of 14 & 4 of 5 \\
Transitive/Intransitive & 18 of 32 & 18 of 33 & 5 of 13 & 12 of 74 & 0 of 14 & 1 of 5 \\
\hline
\end{tabular}




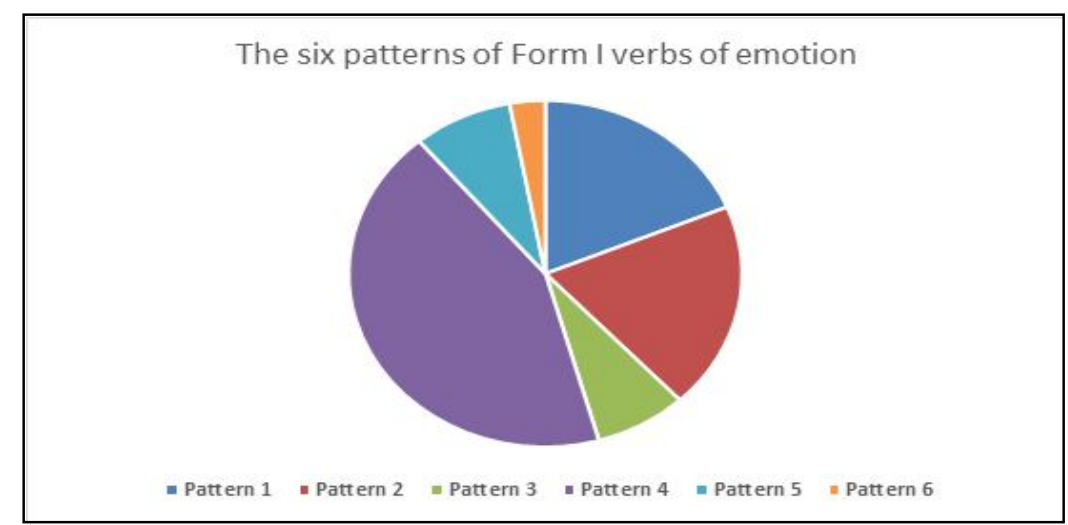

Figure 2: Morphological patterns represetations of Form.

In cases where a root has more than one Form 1 verb with different patterns, these verbs are sometimes polysemous. Where a root has more than one Form I verb with different patterns, polysemy may occasionally be found among Form I verbs. For example, the root $w$-j- $l$ produces three Form I verbs: (i) a transitive verb wajal 'to fear' with the pattern $C_{1} a C_{2} a C_{3}-y a C_{1} C_{2} u C_{3}$; (ii) an intransitive verb wajil

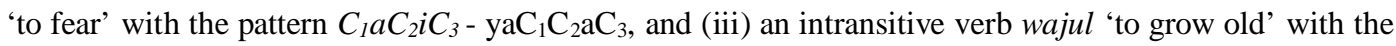
pattern $C_{1} a C_{2} u C_{3}-y a C_{1} C_{2} u C_{3}$ which does not belong to the semantic class of emotion.

\subsection{Verbal derivatives}

This study states that the verb derivation involves two morphological stages: root-to-Form I stage (the base form stem); and Form I-to-derived verb stem (Form II - Form X), as illustrated in Figures 3 and 4 and Table 4 below. This study argues that the Form I verb stem is the input for deriving nine derived verb stems (Form II - Form X) which are the output of verbal derivation. The derivation of these verb stems is governed by canonical patterns; however, not all of the nine verb stems (Form II - Form X) are derived from a given Form I stem, i.e. some of the nine derived forms from a given root do not exist in Arabic dictionaries. Thus, there is a variation in deriving them, i.e. not all Form II - Form X stems can be derived from a given Form I stem. In the following two figures, there are two examples: (1) from the root s.r.r 'to please', we have six derived verb forms as illustrated in Figure 3; while in (2) from the root $s .{ }^{c} . d$ 'to be happy' we have only four derived verbs, as illustrated in Figure 4.

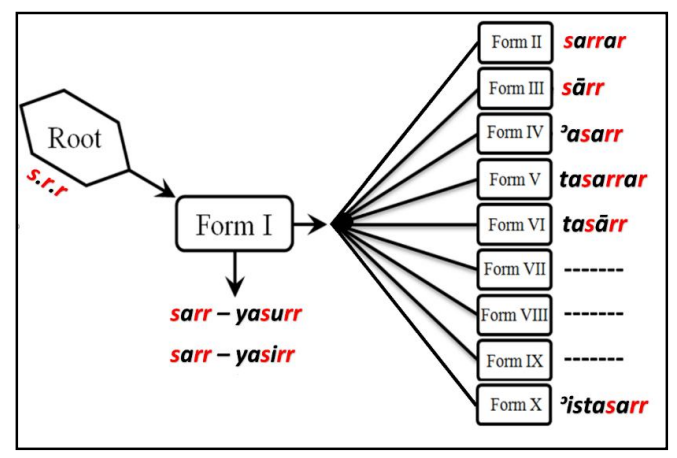

Figure 3: Verbal derivation from the root s.r.r 


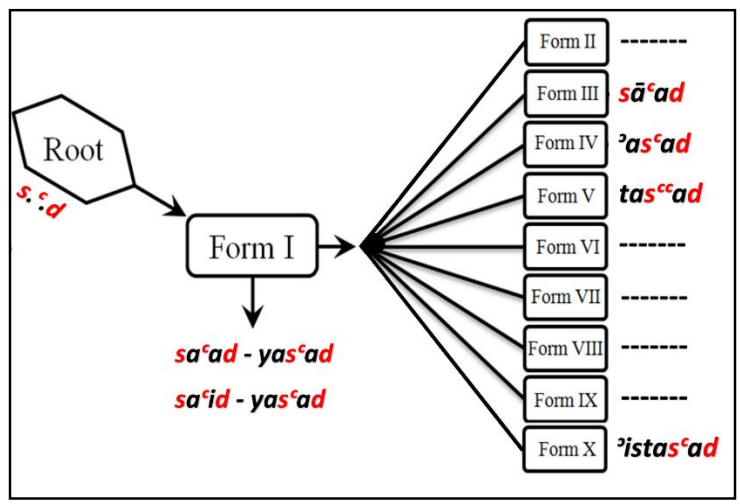

Figure 4: Verbal derivation from the root $s .^{c} . d$

This variation in deriving the Form II - Form X leads to the phenomena of undergeneration or overgeneration. Undergeneration exists when a semantically valid verb is not derived and is not found in Arabic dictionaries, while overgeneration exists when a semantically invalid verb is derived.

In Table 4, an example of a highly derivable verb form is from the root $b-h-j$ 'to feel happy' where seven out of nine verb forms are successfully derived: Forms I, II, III, IV, V, VI, VIII, and X. Forms VII and IX are not semantically valid to be derived from the root $b-h-j$ and Form VII seems to be rarely derived to refer to verbs of emotion. Note that no single case was reported of the use of Form IX with verbs of emotion. This may be attributed to the fact that such a form is semantically restricted to colour, beauty, and disability.

Table 4: Verbal derivation of Form I - Form X

\begin{tabular}{|c|c|c|c|c|}
\hline Form & Root & Pattern & Derived form & $\begin{array}{r}\text { English Gloss } \\
\end{array}$ \\
\hline Form I & $b-h-j$ & $C_{1} a C_{2} a C_{3}$ & bahaj & 'to feel happy' \\
\hline Form II & $b-h-j$ & $C_{1} a C_{2} C_{2} a C_{3}$ & bahhaj & 'to make someone happy' \\
\hline Form III & $b-h-j$ & $C_{1} \bar{a} C_{2} a C_{3}$ & bāhaj & 'to be happy with someone' \\
\hline Form IV & $b-h-j$ & ${ }^{a} a C_{1} C_{2} a C_{3}$ & ${ }^{\supset a b h a j}$ & 'to make someone happy’ \\
\hline Form V & $b-h-j$ & $t a C_{1} a C_{2} C_{2} a C_{3}$ & tabahhaj & 'to feel happy' \\
\hline Form VI & $b-h-j$ & $t a C_{1} \bar{a} C_{2} a C_{3}$ & tabāhaj & 'to be pleased with someone' \\
\hline Form VII & $\underline{d}-c_{-}^{c} r$ & ${ }^{\mathrm{in}} C_{1} a C_{2} a C_{3}$ & ind $a^{c} a \boldsymbol{r}$ & 'to be afraid of' \\
\hline Form VIII & $b-h-j$ & ${ }^{2} C_{1} t_{a} C_{2} a C_{3}$ & ibtahaj & 'to rejoice at' \\
\hline Form IX & $h-m-r$ & ${ }_{i} C_{1} C_{2} a C_{3} C_{3}$ & ihmarr & 'to be red' \\
\hline Form X & $b-h-j$ & ${ }^{2} i s t a C_{1} C_{2} a C_{3}$ & istabhaj & 'to be or become rejoiced' \\
\hline
\end{tabular}

In the following sections, a comprehensive analysis of Forms II, III, IV, V, VI, VII, VIII, and X is provided. This comprehensive analysis involves three aspects: word-formation analysis of each verbal form; syntactic behaviour of each verbal form in terms of transitivity; and the existence of underived verbal forms in Jordanian dialect. 


\section{Form II analysis}

\subsection{Formation of Form II}

The stem of Form II has a single morphological pattern $C_{1} a C_{2} C_{2} a C_{3}$ for perfect tense and $y u C_{1} a C_{2} C_{2} i C_{3}$ for the imperfect tense. At the syllabic level of analysis, it comprises two heavy syllables $C V C$ and $C V C$. This form is derived from Form I by duplicating the second root consonant. Its pattern includes slots of four consonants and slots of two vowels as exemplified in Figure 5. Analysing a corpus of 100 roots shows that only 66 derive from Form II verb stems, that is $66 \%$. These 66 Form II verbs do exist in Arabic dictionaries, while 34 do not.

\subsection{Transitivity of Form II}

Unlike Form I verbs of emotion, there is a radical change in the syntactic behaviour of Form II verbs. Most Form II verbs are transitive (62 out of 66) while the remaining four are intransitive. For example, the Form I verb xajal 'to be ashamed of' is intransitive whereas the Form II verb xajjal 'to cause someone to feel shame' is transitive.

\subsection{Existence of underived Form II in Jordanian dialect}

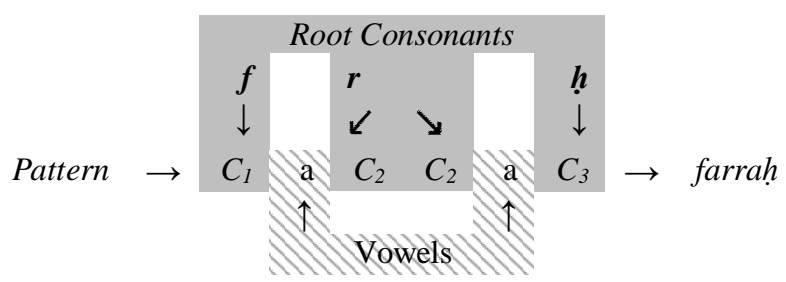

Figure 5: Pattern-root representation of Form II

As only 66 Form II verbs are derived from 100 roots, 44 verbs do not exist in Standard Arabic and Modern Standard Arabic. To prove the existence of a given word in Arabic, it is necessary to check its reliability and usage in Arabic dictionaries. Even so, these 44 verbs that are not found in the dictionaries could potentially be derived if they are meaningful and valid semantically. Table 5 gives examples of five Form II verbs of emotion which are reported in Jordanian Arabic although not found in Arabic dictionaries. These verbs share the same morphological pattern of Form II and express an emotional meaning. 
Alshdaifat

Table 5: The existence of undictionaried Form II in Jordanian Arabic

\begin{tabular}{llcl}
\hline \multicolumn{1}{c}{ Form I } & \multicolumn{1}{c}{ Meaning } & Form II & \multicolumn{1}{c}{ Meaning } \\
\hline$q a z z$ & 'to feel disgusting' & $q a z z a z$ & 'to make someone feel disgusting' \\
$k a^{\prime} i b$ & 'to feel cheerless' & $k a^{\text {s}} a b$ & 'to make someone feel cheerless' \\
qaliq & 'to feel anxious' & $q a l l a q$ & 'to make someone feel anxious' \\
haqid & 'to feel rancorous' & haqqad & 'to make someone feel rancorous' \\
$z a^{c} i l$ & 'to feel sad' & $z a^{c c} a l$ & 'to make someone feel sad' \\
\hline
\end{tabular}

\section{Form III analysis}

\subsection{Morphological Formation}

The Form III stem is governed by the morphological pattern $C_{1} \bar{a} C_{2} a C_{3}$ for the perfect aspect and $y u C_{1} \bar{a} C_{2} i C_{3}$ for the imperfect aspect. At the syllabic level of analysis, the form is produced through vowel lengthening; the new form comprises two heavy syllables $C V V$ and $C V C$. In terms of vowel melody, this pattern is formed by interdigitating the vowels $-\bar{a}-a$ - between the three root consonants, as illustrated in Figure 6. The derivation among verbs of emotion is merely $32 \%$.

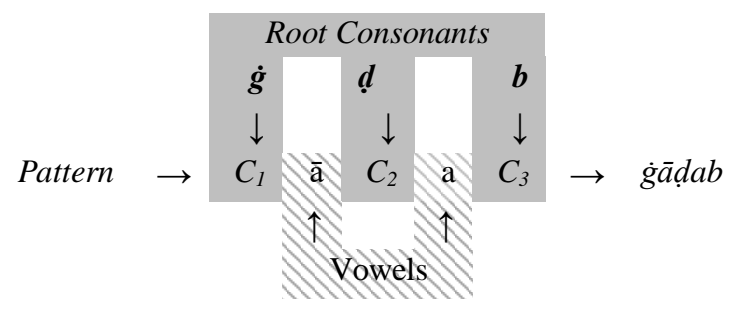

Figure 6: Pattern-root representation of Form III

\subsection{Transitivity of Form III}

Form III constitutes mainly transitive verbs similar to Form II counterparts. Out of the 32 Form III derived verbs of emotion, 25 are transitive, e.g. 'a $a t a b$ 'to admonish', derived from the Form I verb 'atab 'to blame'. In contrast, six Form III verbs could be used transitively or intransitively according to the context, such as the verb d़̄àgan 'to vie with someone in hate' derived from the intransitive verb dagin 'to bear a grudge'. Only one of the 32 Form III verbs is intransitive hărad, although it does not express an emotion (hāradat 'she ceased to yield milk') despite its Form I verb ḥarid meaning 'to feel angry'.

\subsection{Existence of Form III in Jordanian dialect}

Some Form III verbs of emotion are reported in Jordanian dialect, but not in Classical Arabic or Modern Standard Arabic. These verbs share the same morphological pattern and express an emotional meaning that is compatible with the default meaning of Form III in terms of the two entities involved in an action or an interchangeable state. Table 6 shows three examples of Form III that are found in Jordanian Arabic. 
The Formation of Verbs of Emotion in Arabic

Table 6: The existence of undictionaried Form III in Jordanian Arabic

\begin{tabular}{llll}
\hline Form I & Meaning & Form III & Meaning \\
\hline$x a j i l$ & 'to feel shy' & $x \bar{a} j a l$ & 'to be shy with someone' \\
$z a c i l$ & 'to feel angry' & $z \bar{a} c a l$ & 'to be angry with someone' \\
$l a w i^{c}$ & 'to feel anguish' & $l \bar{a} w a^{c}$ & 'to feel anguish with someone' \\
\hline
\end{tabular}

\section{Form IV analysis}

\subsection{Morphological Formation of Form IV}

The Form IV stem is derived from the Form I stem, using the morphological pattern ${ }^{a} a C_{l} C_{2} a C_{3}$ in the perfect tense and the pattern $y u C_{1} C_{2} i C_{3}$ in the imperfect tense. At the syllabic level of analysis, this pattern comprises two heavy syllables $C V C$ and $C V C$. It has a prefix that has an initial glottal stop and a vowel infix, as illustrated in Figure 7. 83 Form IV verbs have been derived from the 100 roots.

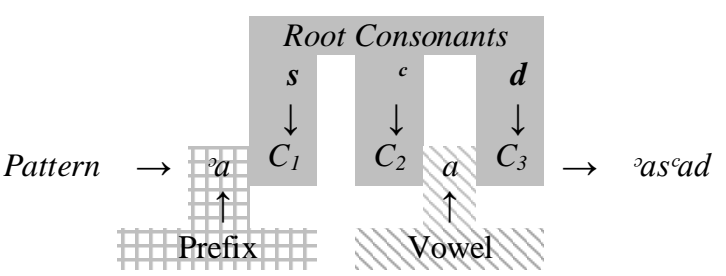

Figure 7: Pattern-root representation of Form IV

\subsection{Transitivity of Form IV}

The vast majority of Form IV verbs of emotion, 81 out of 83, are transitive and only two intransitive. Its prefix ( $\left.{ }^{a} a-\right)$ is called the prefix of transitivity, which changes intransitive Form I verbs to transitive in Form IV. For example, the transitive Form IV verb ‘afrah 'to gladden' is derived from the intransitive Form I verb farih 'to be glad or happy'. The two intransitive Form IV verbs have no ermotional meaning, although their Form I verbs are emotional. These two verbs are: ‘alhaf 'to be stingy' derived from the Form I verb lahif 'to grieve for', and 'ahāb 'to call out' derived from the Form I verb $h \bar{a} b$ 'to fear'.

\subsection{Existence of Form IV in Jordanian dialect}

Only 17 Form IV verbs are not derived from the 100 roots; in Jordanian dialect, only one of these 17 Form IV exists. The lack of this structure may be because this Form starts with the glottal stop consonant which is not preferred in colloquial dialects. The only verb found in the Jordanian dialect, is ${ }^{\circ} a f j a^{c}$ "to make someone feel shocked', derived from the Form I verb faja ${ }^{c}$ 'to feel surprised'.

\section{Form $V$ analysis}

\subsection{Formation of Form $V$}

The Form $\mathrm{V}$ verb stem has the morphological pattern $t_{a} C_{1} a C_{2} C_{2} a C_{3}$ in the perfect tense and $y_{a t a C_{1}} a C_{2} C_{2} a C_{3}$ in the imperfect tense. It is derived from Form I by prefixing $t a$ - and duplicating the 
second root consonant, as in the verb ta assaf 'to feel sorry' illustrated in Figure 8. The syllabic structure of this form is $\mathrm{CV} / \mathrm{CVC} / \mathrm{CVC}$, starting with the light syllable (CV) and followed by two heavy syllables (CVC). 64 verbs are derived from the 100 roots. Buckley (2004:401; see also Ryding 2005; Mashaqba 2015; Laks et al 2019) comments that "Form V verbs are derived from Form II verbs"; however, this study finds that 16 Form $\mathrm{V}$ verbs of emotion do not have Form II origins, such as the Form $\mathrm{V}$ verb tawajjas 'to feel fear' which has no Form II verb.

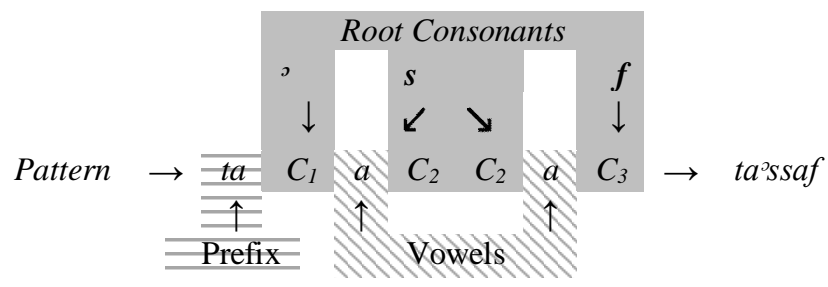

Figure 8: Pattern-root representation of Form V

\subsection{Transitivity of Form V}

Unlike Forms II, III, and IV which are mainly transitive, the derived Form V verbs are mostly intransitive:40 of the 64 Form V verbs are intransitive and 24 transitives. Another feature here is that some Form V verbs act syntactically, unlike the previous derived forms, as with the intransitive Form V verb tagayyaz 'to feel angry’ which is derived from a transitive Form I verb $\dot{g} \bar{a} z$ 'to enrage'.

\subsection{Existence of Form $V$ in Jordanian dialect}

Three Form V verbs of emotion that do not exist in Arabic dictionaries are used in Jordanian dialect. These are: (1) talaww $w^{c}$ 'to feel sick with love' derived from the Form I verb $l \bar{a}^{c}$ 'to torture in love'; (2) tašaffaq 'to ask for pity' derived from Form I šafiq 'to fear for'; and (3) targ் $\dot{g} a b$ 'to show desire for someone/something' derived from Form I ragib 'to wish'.

\section{Form VI analysis}

\subsection{Morphological Formation of Form VI}

Form VI verbs have the morphological pattern $\operatorname{ta}_{1} \bar{a}_{1} C_{2} a C_{3}$ for the perfect tense and the pattern ${ }_{y a t a} C_{1} \bar{a} C_{2} a C_{3}$ for the imperfect tense. Form VI is derived from Form I by prefixing ta- and melodic overwriting of Form I with vocalic melody $\bar{a}$ - $a$ as exemplified by the verb takārah 'to hate', shown in Figure 9. This form has fewer derivations than the previous verb forms, only 32. Unlike other studies (Watson 2006: 432) that consider Form VI to be derived from Form III, this study finds 13 Form VI verbs that do not have Form III verbs. 
The Formation of Verbs of Emotion in Arabic

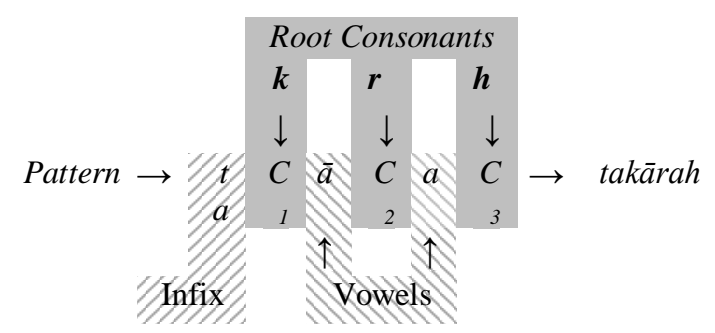

Figure 9: Pattern-root representation of Form VI

\subsection{Transitivity of Form VI}

The majority of the derived Form VI verbs are intransitive, 28 out of 32; for example, talāwam 'to blame oneself' is derived from the Form I transitive verb lām 'to blame'. Only four Form VI verbs are transitive, including takārah 'to hate each other' which is derived from the transitive Form I verb karih 'to hate'.

\subsection{Existence of Form VI in Jordanian dialect}

Two Form VI verbs of emotion that do not exist in Arabic dictioanries are used in the Jordanian dialect; one is transitive: tahāyab Ahmad Fatima 'Ahmad feared Fatima' and the other is intransitive: $\operatorname{taz} \bar{a} c a l$ Ahmad and Fatima 'Ahmad and Fatima were angry with each other'.

\section{Form VII analysis}

\subsection{Morphological Formation of Form VII}

Form VII verbs are derived from Form I verbs by prefixing ${ }^{i n}$ - and melodic overwriting the vocalic melody $-a-a$-, such as the verb 'inzac $a j$ 'to feel upset', as clarified in Figure 10. The Form VII verb stem has the morphological pattern ${ }^{2} i n C_{1} a C_{2} a C_{3}$ in the perfect tense and the pattern $y a n C_{1} a C_{2} i C_{3}$ in the imperfect tense. This form has the fewest derived verbs of emotion, 12.

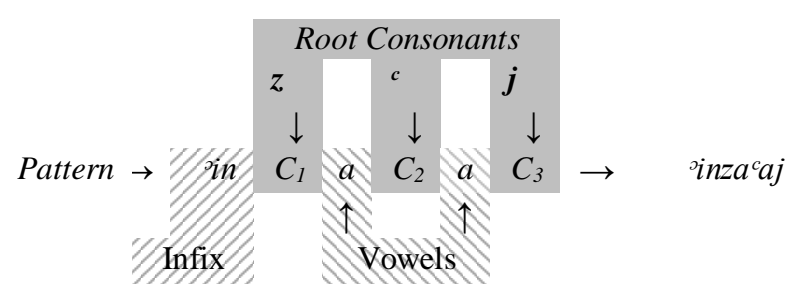

Figure 10: Pattern-root representation of Form VII

\subsection{Transitivity of Form VII}

All 12 Form VII verbs of emotion are intransitive. In many cases they are derived from transitive Form I verbs such as the Form VII verb inkabat 'to be suppressed emotionally' that is derived from the Form I transitive verb kabat 'to suppress'. 


\subsection{Existence of underived Form VII in Jordanian dialect}

Form VII is commonly used in Arabic dialects, even though it is largely dedicated to tangible meanings, and a number of Form VII verbs of emotion which are not found in Arabic dictionaries do exist in Jordanian dialect. These Form VII verbs convey the meaning of passive Form I verbs; see Table 7.

Table 7: The existence of undictionaried Form VII in Jordanian Arabic

\begin{tabular}{llll}
\hline Form I & Meaning & Form VII & Meaning \\
\hline habb & 'to love' & inhabb & 'to be \\
haraj & 'to embarrass' & inharaj & 'to feel \\
hasad & 'to envy' & inhasad & 'to to be \\
karih & 'to hate' & inkarah & 'to be hated' \\
$r a c a b$ & 'to scare' & inracab & 'to be scared \\
\hline
\end{tabular}

\section{Form VIII analysis}

\subsection{Morphological Formation of Form VIII}

Form VIII verbs have the morphological ${ }^{2} i C_{1} t a C_{2} a C_{3}$ for the perfect tense and $y u C_{1} \bar{a} C_{2} i C_{3}$ for the imperfect tense. At the syllabic level of analysis, they comprise four syllables: one heavy syllable followed by three light syllables $C V C, C V, C V$, and $C V$. This stem is formed by prefixing ${ }^{i} i$, infixing $t-$, and melodic overwriting the vocalic melody $-a-a$ - such as ${ }^{2} i k t a^{\circ} a b$ 'to be grieved', as illustrated in Figure 11. The percentage of Form VIII verbs derived from the 100 roots is 39.

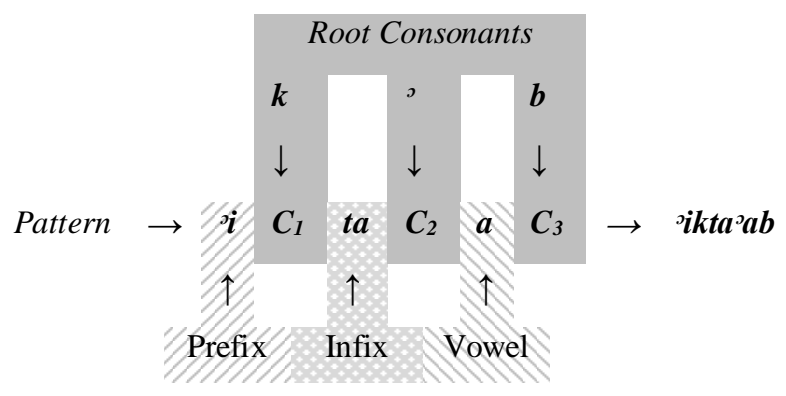

Figure 11: Pattern-root representation of Form VIII

\subsection{Transitivity of Form VIII}

Form VIII verbs of emotion are mainly intransitive: 25 as against 14 transitive. In some cases, intransitive Form VIII verbs are derived from transitive Form I verbs, such as the verb ${ }^{i} i t \bar{a}^{c}$ ' to burn or pine away (with love or grief)' that is derived from the transitive Form I verb $l \bar{a}^{c}$ 'to torture in love'.

\subsection{Existence of underived Form VIII in Jordanian dialect}

There are two cases in which derived Form VIII verbs do not exist in Arabic dictionaries. These refer to emotions related to their Form I'meanings: (1) the intransitive verb 'irthab 'to be frightened' is 
derived from the transitive Form I verb rahib 'to scare'; and (2) the intransitive 'iltām 'to be blamed' is derived from the transitive Form I verb lām 'to blame'.

\section{Form $X$ analysis}

\subsection{Morphological Formation of Form X}

The Form $\mathrm{X}$ verb has the morphological pattern ${ }^{2} i s t a C_{1} C_{2} a C_{3}$ in the perfect tense and yastaC $C_{1} C_{2} i C_{3}$ in the imperfect tense. The syllabic structure of this form is three heavy syllables $C V C, C V C$ and $C V C$ ( ${ }^{i} i / t a C_{1} / C_{2} a C_{3}$ ). Form $\mathrm{X}$ is derived from Form I by prefixing ${ }^{i s t a-}$ and melodic overwriting the vocalic melody $-a$ - as illustrated in Figure 12, where the verb 'ista'taf 'to ask for someone's sympathy' is derived from the Form I verb 'ațaf 'to sympathise with'. The percentage of derived Form X verbs is 26.

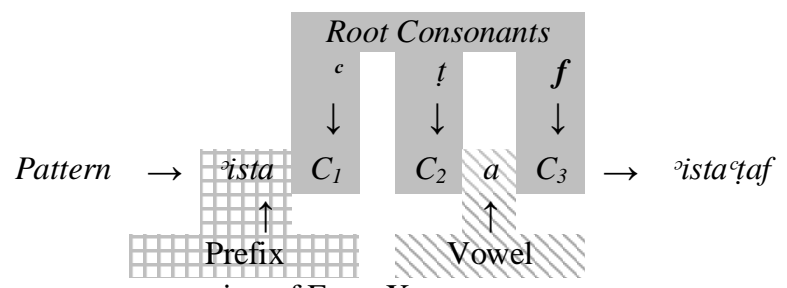

Figure 12: Pattern-root representation of Form $X$

\subsection{Transitivity of Form $X$}

Form $\mathrm{X}$ verbs of emotion include more transitive than intransitive verbs; 16 are transitive, such as istahwā 'to attract, to appeal to' and 10 are intransitive, such as 'istayas 'to lose hope (of)'. In many cases there is no change in the behaviour of Form $\mathrm{X}$ verbs, i.e. if a Form $\mathrm{X}$ verb is derived from an intransitive Form I verb, it will remain intransitive, such as 'istag̣̣dab 'to get angary' derived from the intransitive Form I verb gadib with the same meaning.

\subsection{Existence of Form $X$ in Jordanian dialect}

Three Form $\mathrm{X}$ verbs of emotion in Jordanian dialect do not exist in Arabic dictionaries: (1) 'ist ${ }^{\supset} a s a f$ 'to ask for excuse' derived from the Form I verb 'asif 'to feel sorry'; (2) ‘istabgad 'to consider something hateful' derived from Form I bagad 'to hate'; and (3) 'istalhaf 'to sigh for' derived from Form I lahaf 'to yearn'.

\section{Conclusion}

This study has provided a comprehensive analysis of the formation of Arabic verbs within the semantic field of emotions, considering that verbs within a given semantic field act identically, morphologically and syntactically. With regard to Form I verbs of emotion, the data analysis has shown a strong relationship between the semantics and the morphological pattern. Among the six patterns of Form I, $74 \%$ of verbs of emotion tend to follow the pattern $C_{1} a C_{2} i C_{3}-y a C_{1} C_{2} a C_{3}$, even though this pattern is not commonly used in Arabic. 
The derivation of verbs in Arabic is governed by applying a canonical pattern to a given root to produce Form I - Form X verbs. However, the current study has found that not all verbs belonging to Form II - Form X can be derived from a given root; thus, there is a variation in deriving each verbal form (Form II - Form X). For example, from the root f.r.h 'to be happy', only three verbs are derived: Form I farih, Form II farrah, and Form IV `afrah.

At the derivational level of the augmented verbs of emotion, the data analysis indicates variation in their derivation, as shown in Figure 12. The highest number of derived forms is Form IV (83 verbs), followed by Form II (66), Form V (64), Form VIII (39), Form III (32), Form VI (32), Form X (26), Form VII (12), and Form IX (0). The absence in Form IX is because this form is semantically restricted to colour, beauty, and disability. Further work needs to be done on other semantic fields to determine their tendencies towards certain verbal forms.

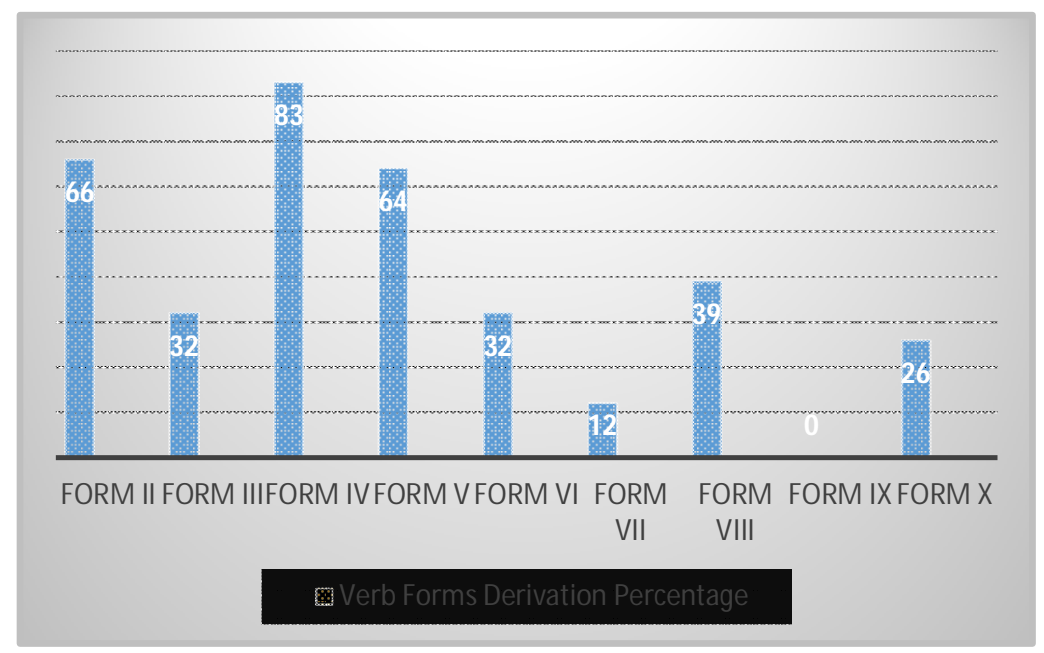

Figure 13: Variation in deriving the augmented forms (Form II - Form X)

Authors such as Ryding (2005: 543) recognise dependence between Form III and Form VI, but the current study found that not every Form VI is dependent on its equivalent Form III, because there are only 13 roots from which Form VI verbs are derived.

Syntactically, the current study has determined the behaviour of each verbal form in terms of their transitivity. The majority of the verbal forms are intransitive, with these percentages: Form VII (100\%), Form VI (88\%), Form I (82\%), Form VIII (64\%), Form V (63\%), and Form X (63\%). In contrast, three verbal forms tend to be transitive: Form IV (98\%), Form II (94\%), and Form III (78\%).

The study also highlights a phenomenon not yet studied related to existing verbal forms of emotion used in Jordanian dialect that are not used in Standard or Modern Standard Arabic, even though these verbs have the same morphological patterns as in Standard Arabic. 24 Jordanian dialect verbal forms are found: 5 Form II verbs, 3 Form III verbs, 1 Form IV verb, 3 Form V verbs, 2 Form VI verbs, 5 Form VII verbs, 2 Form VIII verbs, and 3 Form $\mathrm{X}$ verbs. 
The Formation of Verbs of Emotion in Arabic

The results of this study have thrown up many questions in need of further investigation on verbs in other semantic fields, such as verbs of motion, social interaction, mental process, and colouring. The results could also be useful for researchers working on NLP applications such as verb wordnet and ontology, and e-dictionaries.

\title{
اشتقاق أفعال المشاعر في اللُفة العربيّة: دراسةٌ تحليليّة وصفيّةٌ عبدالله الشديفات قسم اللفة العربية، الجامعة الأردنيّة، الأردن
}

\begin{abstract}
الملخص
تهدف هذه الدراسة إلى إبراز خصائص اشتقاق الأفعال المجردة والمزيدة ضمن حقل المشاعر الدَّلاِّ في اللُّة العربيّة.

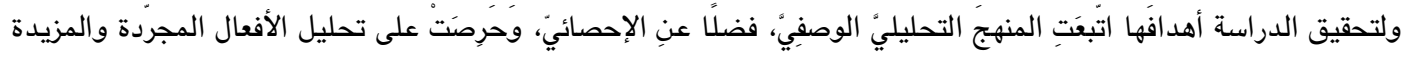
التي وقفت عليها منطلقةً من ثلاثة محاور، هي: التحليل الصرفيَ لاشتقاقها، وتحليل خصائصها النَحْوِيّة من حيثُ التعدي واللزوم، والتحقّ من وجود أفعال مزيدة معياريّة الوزن في اللهجة الأردنيّة ليست واردة في المعاجم العربيّة. وانطلقت الدراسة من 100 جذر ثلاثيّ ضمن حقل المشاعر، وتتبَعت اشتقاق الأفعال المجردة والمزيدة منها، ثمْ خَلُصَتْ إلى أنْ الفعل الثلاثيّ المجرد يميل إلى استخدام الوزن الصرفيّ مكسور العين في الماضي، وفي ما يتعلّق بالأفعال المزيدة توصلّت الدراسة إلى وجود تباين في اشتقاقها؛ إذ جاءت نِسَبْ أفعال المشاعر المُشتقة من 100 جذر ضمن ثمانية أوزان على النّحو الآتي: أفعلَ - يُفِلُ

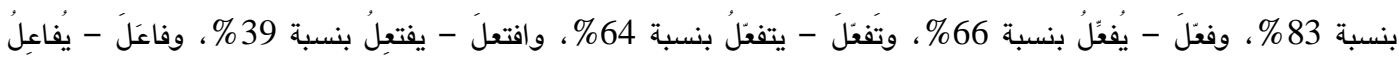
بنسبة 32\% ، وتفاعَلَ - يتفاعلُ بنسبة 32\%، واستفعلَ - يستفعلُ بنسبة 26\%، وانفعلَ - ينفعلُ بنسبة 12\%، أمَا وزن

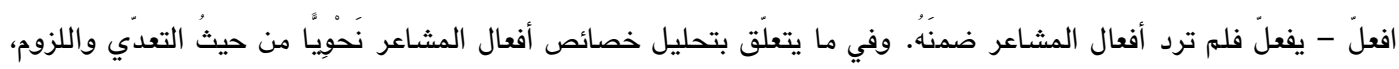
توصلّت الدراسة إلى تحديد التعدي واللزوم فوجدت أفعالاً تميل إلى التعدي، هي: أفعلَ - يُفعِلُ بنسبة 98\% ، وفعَلَ - يُفِّلُ بنسبة 94\%، وفاعَلَ - يُفاعِلُ بنسبة 78\%، وفي المقابل وجدت الدراسة أفعالاً تميل إلى اللزوم، هي: انفعلَ - ينفعلُ بنسبة 100 \% وتفاعلَ - يتفاعلُ بنسبة 88\% ـ كما سلُطت الدراسة الضَّوء على ظاهرة لُفويّة تتمثل في وجود 25 فعلاً مزيداً من أفعال المشاعر مُستخدمةً في اللهجة الأردنية ومتوافقةً مَعَ الأوزان الصرفيّة القياسيّة، على الرغّم من عدم وجودها في المعاجم العربية القديمة والحديثة، وترى الدراسة أنْ وجود هذه الأفعال القياسيّة في اللهجات يُسهم في مَلْ جدول اللُّة الفصيحة التصريفيّ. الكلمات المفتاحية: أفعال المشاعر، الاشتقاق، الأفعال المجردة، الأفعال المزيدة، اللهجة الأردنيّة.
\end{abstract}




\section{References}

Al Huneety, Anas. 2015. "The phonology and Morphology of Wadi Mousa Arabic." PhD diss., University of Salford.

Alshdaifat, Abdallah. 2015. "The formation of Nominal Derivatives in the Arabic Language with a View to Computational Linguistics." PhD diss., University of Salford.

Ekman, Paul. 1972. Universals and Cultural Differences in Facial Expressions of Emotions. In Cole, J. (Ed.), Nebraska Symposium on Motivation. 207-282. Lincoln, NB: University of Nebraska Press.

Irshied, Omar. 1985. The Phonology of Arabic: Bani Hassan A Bedouin Jordanian Dialect. PhD diss., University of Illinois.

Levin, Beth. 1993. English Verb Classes and Alternations: A Preliminary Investigation. Chicago: University of Chicago Press.

Mashaqba, Basel. 2015. “The Phonology and Morphology of Wadi Ramm Arabic.” PhD diss., University of Salford.

Plutchik, Robert. 1980. A General Psychoevolutionary Theory of Emotion. In Theories of Emotion 3-33. London: Academic press.

Ryding, Karin. 2005. A Reference Grammar of Modern Standard Arabic. Cambridge: Cambridge University Press.

Laks, Lior, Hamad, Ibraim, and Saiegh-Haddad, Elinor. 2019. Verbal patterns in Palestinian Arabic. The Mental Lexicon 14 (2): 209-236.

Vendler, Zeno. 1968. Adjectives and Nominalizations. Berlin: Walter De Gruyter.

Watson, Janet. 2002. The Phonology and Morphology of Arabic. Oxford: Oxford University.

Watson, Janet. 2006. Arabic as an Introflecting Language. ed. Keith Brown. In the Encyclopaedia of Language and Linguistics. Amesterdam: Elsevier, 2nd edition. 431-434. 